\title{
The Relationship between Exclusive Breastfeeding and Tonsillitis in Children aged o-7 Years
}

\author{
Hanni Wardhani, Melati Citra Rachmasari, Agustina Puryani
}

Indonesian Doctors Internship Program, DKT Slamet Riyadi Hospital, Surakarta

\section{ABSTRACT}

Background: Tonsillitis is a type of acute respiratory infection (ARI) that is most common in children and toddlers. This study aims to determine the relationship of exclusive breastfeeding to tonsillitis in children aged 0-7 years at the Pajang Health Center, Surakarta, Central Java, Indonesia.

Subjects and Method: This was a cross sectional study conducted at Pajang community health center, Surakarta, Central Java, Indonesia. A total of 30 children aged $<7$ years was selected for this study. The dependent variable was tonsillitis. The independent variable was the history of exclusive breastfeeding. The data were collected by questionnaire and physical examination. The data were analyzed using the Fischer's exact test.
Results: Non-exclusive breastfeeding increases the risk of tonsillitis in children aged $0-7$ years $(\mathrm{OR}=7.00 ; 95 \% \mathrm{CI}=1.29$ to $37.91 ; \mathrm{p}=$ 0.024).

Conclusion: Children aged 0-7 years who do not get exclusive breastfeeding are at risk of having tonsillitis than children who get exclusive breastfeeding.

Keywords:tonsillitis, exclusive breastfeeding

\section{Correspondence:}

Hanni Wardhani. Indonesian Doctors Internship Program, DKT Slamet Riyadi Hospital, Surakarta, Jl. Brigjen Slamet Riyadi 321, Surakarta 57148, Central Java. Email: hanniwardha@yahoo.com. Mobile +6282299801852

Cite this as:

Wardhani H, Rachmasari MC, Puryani A (2020). The Relation between Exclusive Breastfeeding and Tonsilitis in Children aged 0-7 Years. J Matern Child Health. 5(2): 243-250. https://doi.org/10.26911/thejmch.2020.05.03.03

cc (i) (- Journal of Maternal and Child Health is licensed under a Creative Commons EY NC SA Attribution-Non Commercial-Share Alike 4.0 International License.

\section{BACKGROUND}

Public health is part of the overall human development effort in which the development of public health, among others, starts with children's health efforts as early as possible (Ministry of Health, 2016).

The level of public health is assessed from various aspects, one of which is the infant mortality rate (IMR). The majority of child deaths in Indonesia occur in the newborn period (neonatal). The possibility of a child dying is 19 per thousand during the neonatal period, 15 per thousand from ages 2 to 11 months and 10 per thousand from ages 1 to 5 years. Nevertheless the cause of death of children due to infection is still the main focus of the government (UNICEF In- donesia, 2012). Until now, ARI is still a serious health problem for the people of Indonesia. The main causes of death of children and toddlers according to Bappenas (2015) are respiratory infections (ARI), diarrhea, neurological diseases and typhoid fever. One type of ARI that often appears is tonsillitis. Tonsillitis is an inflammation of the tonsils caused by bacteria or viruses, the process can be acute or chronic (Riskesdas, 2010; Dorland, 2012; Campisi et al, 2003).

Epidemiological data on ear and throat (ENT) in seven provinces in Indonesia shows that chronic tonsillitis occupies the highest position after acute nasopharyngitis, which is 3.8\% (Rukmini, 2003; 
Wardhani $\mathrm{H}$ et al./ The Relation between Exclusive Breastfeeding and Tonsilitis in Children

Farokah, 2007; Sapitri, 2013). Tonsillitis is most common in subtropical countries. In cold climate countries, the incidence is higher than in tropical countries, Streptococcus infections occur throughout the year, especially in winter (Rusmarjono, 2003; Desai et al., 2008).

Based on data from the Surakarta City Health Office, tonsillitis is among the 10 most common diseases found in Primary Health Services (Profkes, 2014). In order to reduce morbidity and mortality rates for children, the United Nation Children Fund (UNICEF) and the World Health Organization (WHO) recommend exclusive breastfeeding for at least 6 months, solid food should be given after the child is 6 months old, and breastfeeding continued until the child is two years old (WHO, 2016). In 2003, the Indonesian government changed its long-standing recommendation of exclusive breastfeeding from 4 to 6 months (Ministry of Health, 2014).

Exclusive breastfeeding is not giving infants food or other drinks, including water, other than breastfeeding (except drugs and vitamin or mineral drops) exclusive limits if consumption other than breastfeeding is less than $100 \mathrm{~g} /$ day. If more than that is called partial. Coverage of exclusive breastfeeding in Surakarta in 2010 was 69.It is $97 \%$, higher than the national average coverage of $55.7 \%$ and WHO target of 50\% (Surakarta City Health Office, 2010; Ministry of Health, 2016; Pusdatin, 2014; WHO, 2012; Da Costa et al., 2010; Ayton et al., 2015).

Various studies have revealed that exclusive breastfeeding is significantly able to prevent diarrhea, otitis media, multiple sclerosis, and acute respiratory infections. Also prevent insignificantly in diseases of the skin, urinary tract, eyes, and mouth teeth (Stapleton et al, 2012; Ladomenou et al., 2010; Agne et al., 2013; Hanieh et al.,
2015). Studies in developing countries show that infants who get formula milk go out more often than those who get exclusive breastfeeding. And infants who did not get breastfeeding were eight times more hospitalized than those who received breastfeeding (Lauer et al., 2006; Rinne et al., 2005; Satku, 2004; Agne et al., 2013; Martin et al., 2016).

Achieving the target of exclusive breastfeeding coverage and the high incidence of tonsillitis is the background of the authors to conduct study whether there is a relationship between the histories of exclusive breastfeeding with the incidence of tonsillitis in children aged o-7 years.

\section{SUBJECTS AND METHOD}

\section{Study Design}

This was a cross sectional study conducted in March 2019 to April 2019, at the Pajang Health Center, Surakarta, Indonesia.

\section{Population and Sample}

The study population was children aged less than 7 years who come to the Pajang Health Center, Surakarta. A sample of 30 children under 7 years old was selected by consecutive sampling.

\section{Study Variables}

The dependent variable was tonsillitis. The independent variable was exclusive breastfeeding.

\section{Operational Definition of Variables} A history of exclusive breastfeeding was a subject where infants aged o-6 months receive only breastfeeding nutrition without any other food except vitamins, drugs, and minerals. Data obtained through interviews and questionnaires to parents. The measurement scale is categorical, coded $\mathrm{o}$ for exclusive breastfeeding and 1 for not exclusive breastfeeding.

Tonsillitis was inflammation of the tonsils or tonsils. The diagnosis of tonsillitis is made when there is hypertrophy, detritus, 
Wardhani H et al./ The Relation between Exclusive Breastfeeding and Tonsilitis in Children

hyperemia, edema, and exudate in tonsillar examination. Tonsil enlargement can be expressed in $\mathrm{T} 1-\mathrm{T}_{4}$ size. Cody and Thane divides tonsillar enlargement in the following sizes:T1 $=$ medial tonsil border across the anterior pillar to $1 / 4$ anterior-uvula pillar distance; T2= medial tonsillar border crossing $1 / 4$ anterior-uvula pillar distance to $1 / 2$ anterior-uvula pillar distance; $\mathrm{T}_{3}=$ medial tonsillar border beyond $1 / 2$ anterior-uvula pillar distance to $3 / 4$ anterior-uvula pillar distance; $\mathrm{T}_{4}=$ medial tonsillar border beyond $3 / 4$ anterior-uvula pillar distance or more; and The measurement scale is categorical, code $\mathrm{o}$ is not tonsillitis and 1 tonsillitis.

\section{Study Instruments}

History of exclusive breastfeeding is obtained through interviews and questionnaires to parents/ guardians of children. Tonsillitis is obtained through history taking and physical examination.

\section{Data Analysis}

Data were analyzed by Fisher's exact test.

\section{RESULTS}

1. Sample Characteristics

Table 1 shows that the age of the study subjects obtained a minimum of 9 months, a maximum age of 79 months and an average of 44.33 months. Table 2 shows that there were 11 male children (36.7\%) and 19 female children (63.3\%).

Table 1. Sample Characteristics of Continuous Data

\begin{tabular}{lccccc}
\hline Characteristics & N & Mean & SD & Minimum & Maximum \\
\hline Age (month) & 30 & 44.33 & $\mathbf{1 8 . 7 8}$ & 9 & 79 \\
\hline
\end{tabular}

Table 2. Sample Characteristics of Categorical Data

\begin{tabular}{lcc}
\hline Gender & Total & Percentage \\
\hline Male & 11 & $36.7 \%$ \\
Female & 19 & $63.3 \%$ \\
\hline
\end{tabular}

\section{The result of bivariate analysis}

Table 3 shows that from 30 respondents there were 12 people (40.0\%) who had tonsillitis and 18 people (60\%) who did not suffer from tonsillitis. Of the 10 respondents who were not exclusively breastfed there were 7 people (70\%) who had tonsillitis and

Table 3. Relationship of exclusive breastfeeding to the occurrence of tonsillitis in children aged o-7 years at Pajang health center, Surakarta

\begin{tabular}{lcccccc}
\hline \multirow{2}{*}{$\begin{array}{l}\text { bxclusive } \\
\text { breastfeeding }\end{array}$} & \multicolumn{2}{c}{ Tonsillitis } & \multirow{2}{*}{ Total } & \multirow{2}{*}{ OR } & \multirow{2}{*}{ CI 95\% } & \multirow{2}{*}{ p } \\
\cline { 2 - 5 } No & Yes & No & & & & \\
Yes & $7(70.0 \%)$ & $3(30.0 \%)$ & $100.0 \%$ & 7.00 & 1.29 to 37.91 & 0.024 \\
\hline
\end{tabular}

\section{DISCUSSION}

The analysis showed that there was a significant relationship between exclusive breastfeeding and the incidence of tonsillitis in children aged 0-7 years. This study shows that children under 7 years who do
3 people (30.0\%) who did not have tonsillitis, while of the 20 respondents who were given exclusive breastfeeding there were 5 people (25\%) who had tonsillitis and 15 people (75.0\%) who did not experience tonsillitis. 
Wardhani $\mathrm{H}$ et al./ The Relation between Exclusive Breastfeeding and Tonsilitis in Children

The results of this study are in accordance with the theory of Story et al. (2008) where breastfeeding is able to protect infants and children from infectious diseases, including those that have a significant effect, namely diarrhea, otitis media, multiple sclerosis, and respiratory infections. Breastfeeding also contains protein, fat, vitamins, minerals, hormones, enzymes, and growth factors that play a role in preventing infection (Mosca et al, 2017; Nuzrina et al, 2016).

So infants who are exclusively breastfed will be healthier and less sick than infants who are not exclusively breastfed (Dhakal et al., 2017; Kartika et al., 2016; Nannyu, 2008; Widyastuti et al., 2018). Exclusive breastfeeding given to infants properly and correctly provides the immune system or antibodies to the baby's body compared to infants who do not get exclusive breastfeeding so that infants are not susceptible to diseases or infections that often occur in infants, one of them is tonsillitis (Andreas et al., 2015; Khadilkar et al., 2016; Nurjanah, 2015).

The first 1-3 days breastfeeding called colostrum contains 1-17 times more immunity than mature milk in the form of maternal antibodies, in addition there is also complete nutrition for infants, immunoregulators, immunomodulators (Ghodia et al., 2013; Golinelli et al., 2014; Peneau, 2014). Immunomodulator protection from exclusive breastfeeding can increase secretory immunoglobulin A (sIgA). Besides that breastfeeding has a good effect on the good flora in the body of a newborn (Ladomenou et al., 2010; Burke et al., 2014).

These immune substances will protect infants from various diseases such as autoimmune, ear infections, breathing, skin, urinary tract, eyes, digestion, and oral teeth to runny nose (Oktiyani, 2015). The substances contained in breastfeeding are acti- vely able to inhibit and kill bacteria, viruses, fungi, and parasites through a number of immune cells (phagocytes and lymphocytes), antibodies, and immunoglobulins (Nizar et al, 2016; Sulistya-rini, 2013). Breastfeeding also provides long-term protection by stimulating an active immune response that is not present in other food intake (Ladomenou et al., 2010; Mataram 2011).

The results of the study are in accordance with Elfia (2012) that infants who get exclusive breastfeeding will be healthier and rarely experience acute respiratory infection (ARI) compared to infants who do not get exclusive breastfeeding. This study is in line with study which says that exclusive breastfeeding is better because with exclusive breastfeeding children get antibodies from the breastfeeding and prevent ARI in toddlers (Rustam, 2010; Noorhidayah and Widya Sari, 2014).

Regarding the studythat has been done, there is a need for Communication, Information and Education (IEC) for health service institutions to be able to provide health education or promotion to mothers especially those who have babies, toddlers and children and further improve quality services. The public also needs to know about health problems, especially regarding tonsillitis, as well as increase knowledge about health sciences to pay more attention to the nutrition of their children in the future. Further studyneeds to be done with a larger sample, a wider population and more control over external factors that can affect studyresults.

AUTHOR CONTRIBUTION
Hanni Wardhani determined the theme and
title of the study, determined the location
and issues raised, formulated the concept
and design of the study, and analyzed and
interpreted the data. Melati Citra Rachma-
sari calculating sample size and collecting


Wardhani $\mathrm{H}$ et al./ The Relation between Exclusive Breastfeeding and Tonsilitis in Children

data. Agustina Puryani collected data and checked the manuscript.

\section{CONFLICT OF INTEREST}

We declare that there was no conflict of interest.

\section{FUNDING AND SPONSORSHIP}

There is no external funding and sponsorship.

\section{ACKNOWLEDGEMENT}

The author would like to thank the parents/ guardians of children aged o-7 years who have participated in this study.

\section{REFERENCE}

Agne DA, Kwadjode KM, Idohou DN, Diouf A, Guiro AT, Wade S (2013). Energy intake from human milk covers the requirement of 6-month-old senegalese exclusively breast-fed infants. The British Journal of Nutrition, 110(10): 1849-55.

Andreas NJ, Kampmann B, Doare KML (2015). Human breastfeeding: A review on its composition and bioactivity. Journal Elsevier 91: 629-635.

Ayton J, Mei IV, Wills K, Hansen E, Nelson $M$ (2015). Cumulative risks and cessation of exclusive breast feeding: Australian cross-sectional survey. Arch Dis Child. 100:863-868.

Burke RM, Leon JS, Suchdev PS (2014). Identification, prevention and treatment of iron deficiency during the first 1000 days. Journal Nutrients 6(1): 4093-4114.

Campisi P, Tewfik TL (2003). Tonsillitis and its complication. Journal Diagnosis, 99-105.

Da Costa THM, Haisma H, Wells JCK (2010). How much human milk do infants consume? Data from 12 countries using a standardized stable iso- tope methodology. Journal Nutrition. 140: 2227-2232.

Depkes RI (2015). Dukung ibu bekerja beri ASI eksklusif (Support working mothers to give exclusive breastfeeding).

Desai S, Scannapieco FA, Lepore M, Anolik R, Glick M (2008). Disease of the respiratory tract. In: Greenberg MS, Glick M, Ship JA, (eds). Burket's Oral Medicine. Hamilton, Ontario. Petrice Custance, 305 - 306.

Dhakal S, Lee TH, Nam EW (2017). Exclusive breastfeeding practice and its association among mothers of under 5 children in Kwango District, DR Congo. International Journal. Environ. Res. Public Health 14(1): 2-8.

DinasKesehatan Kota Surakarta (2010). Draft perencanaanstrategis 2011-2016. DinasKesehatan Kota Surakarta.

Elfia, Yunita (2012). Hubunganpemberian ASI eksklusifdengankejadian ISPA padabayiusia o-6 bulan di PuskesmasNgresep Semarang (The relationship between exclusive breastfeeding and the incidence of ARI in infants aged 0-6 months at the Ngresep Health Center Semarang. Fakultas Kedokteran UMS (online) (diakses pada tanggal 20 Maret 2019).

Fakh IM, Novialdi, Elmatris (2013). Karakteristik pasien tonsillitis kronik pada anak di bagian THT-KL RSUP Dr. M. Djamil Padang tahun 2013. Jurnal Kesehatan Andalas; 5(2): 436-42.

Farokah, Suprihati, Suyitno S (2007). Hubungan tonsillitis kronis dengan prestasi belajar pada siswa kelas II sekolah dasar di Kota Semarang (Relationship of chronic tonsillitis with learning achievement in grade II elementary school students in the city of Semarang). In: Riyanto WB, 2007. Cermin Dunia Kedokteran No. 155 (THT), Jakarta. 34 (2). 
Wardhani $\mathrm{H}$ et al./ The Relation between Exclusive Breastfeeding and Tonsilitis in Children

Ghodia ML, Patel N (2013). Colostrum - its composition, benefits as a nutraceutical: A review. Curr Res Nutrition Food Science Journal, 1(1): 37-47.

Golinelli LP, Aguila EMD, Paschoalin VMF, Silva JT, Junior CAC (2014). Functional aspect of colostrum and whey proteins in human milk. Journal of Human Nutrition \& Food Science 2(3): 1035 .

Hanieh S, Ha TT, Simpson JA, Thuy TT, Khuong NC, Thoang DD, Tran TD, et al (2015). Exclusive breast feeding in early infancy reduces the risk of inpatient admission for diarrhea and suspected pneumonia in rural Vietnam: A prospective cohort study. BMC Public Health 15:1166.

Herawati S, Rukmini S (2003). Penyakit telinga hidung tenggorok (Throat nose disease). In:drg. Lilian Juwono, 2003. Buku Ajar Ilmu Penyakit Telinga Hidung Tenggorok untuk Mahasiswa Fakultas Kedokteran Gigi. Jakarta. EGC.

Kartika II, Eldawati, Margen (2016). Faktor-faktor yang berhubungan dengan angka kejadian tonsillitis pada anak usia 5-18 tahun di Poliklinik THT RSUD Karawang tahun 2015. Jurnal Kesehatan Bhakti Husada; 3(1): 2332.

Kementrian Kesehatan Republik Indonesia (2016). Profil kesehatan Indonesia 2015. Kementrian Kesehatan Republik Indonesia.

Khadilkar MN, Ankle NR (2016). Anaerobic bacteriological microbiota in surface and core of tonsils in chronic tonsillitis. Journal Of Clinical \& Diagnostic Research; 10(11):3.

Ladomenou F, Moschandreas J, Kafatos A, Tselentis Y, Galanakis E (2010). Protective effect of exclusive breastfeeding against infections during infancy:
A prospective study. Archives of Disease in Childhood, 95(12), 1004.

Lakshman R, Ogilvie D, Ong KK (2009). Mothers' experiences of bottle-feeding: A systematic review of qualitative and quantitative studies. Arch Dis Child;94(8):596-601.

Lauer JA, Betran AP, Barros AJ, de Onis M (2006). Deaths and years of life lost due to suboptimal breast-feeding among children in the developing world: A global ecological risk assessment. Public Health Nutr. 9(6):67385.

Martin CR, Ling PR, Blackburn GL (2016). Review of infant feeding: Key features of breastfeeding and infant formula. Journal Nutrients 8: 279.

Mataram (2011). Aspek imunologi air susu ibu. Jurnal Ilmu Gizi, 2 (1): 37-48.

Mosca F, Gianni ML (2017). Human milk: Composition and health benefits. Medical and Surgical Pediatrics 39 (155): 47-52.

Naanyu V (2008). Young mothers, first time parenthood and exclusive breastfeeding in Kenya. African Journal of Reproductive Health, 12(3), 125- 138.

Noorhidayah, Sari W (2014). Hubungan pemberian ASI eksklusif dengan kejadian ISPA padabalita di Puskesmas Pekauman Banjarmasin (Relationship between exclusive breastfeeding with ARI events in infants at the Pekauman Health Center in Banjarmasin). Sekolah Tinggi Ilmu Kesehatan (STIKes) Sari Mulia Banjarmasin, 6(1): 110.

Nurjanah S (2015). ASI eksklusif meningkatkan perkembangan bayi usia 6-12 bulan di wilayah kerja Puskesmas Banyu Urip Surabaya (Exclusive breastfeeding promotes the development of infants aged 6-12 months in the working area of the Banyu Urip 
Wardhani $\mathrm{H}$ et al./ The Relation between Exclusive Breastfeeding and Tonsilitis in Children

Health Center in Surabaya. Jurnal Kesehatan Masyarakat, 8(2): 221-228. Nuzrina R, Roshita A, Basuki DN (2016). Factors affecting breastfeeding intention and its continuation among urban mothers in West Jakarta: A follow-up qualitative study using critical point contact for breastfeeding. Asia Pacific Journal Clinical Nutrition. 25(1):43-51.

Nizar M, Qamariah N, Muthmainah N (2016). Identifikasi bakteri penyebab tonsillitis kronik pada pasien anak di Bagian THT RSUD Ulin Banjarmasin (Identification of the bacteria that causes chronic tonsillitis in pediatric patients in the ENT Section of Ulin Hospital Banjarmasin ). Jurnal Berkala Kedokteran; 12(2).197-204.

Oktiyani P (2015). Hubungan pemberian ASI eksklusif dengan perkembangan bayi usia 0-6 bulan di wilayah kerja Puskesmas Padang Sari Kota Semarang (The relationship between exclusive breastfeeding and the development of infants aged o-6 months in the working area of the Padang Sari Public Health Center in Semarang

Peneau (2014). Breastfeeding, early nutrition, and adult body fat. Pedriatics Journal. 164(6): 1245-1247.

Profil Kecamatan Bayat (2013). Data demografi Kecamatan Bayat Kabupaten Klaten, tahun 2013.

Profkes (2014). Profil kesehatan Indonesia tahun 2014. Kementerian Kesehatan RI. ISBN 978-602-235-911-1.

Pusdatin, Infodatin RI (2014). Situasi dan analisis ASI eksklusif. Kementrian Kesehatan RI. Pusat Data dan Informasi.

Rinne MM, Gueimonde M, Kalliomaki M, Hoppu U, Salminen SJ, Isolauri E (2005). Similar bifidogenic effects of prebiotic-supplemented partially hy- drolyzed infant formula and breastfeeding on infant gut microbiota. FEMS Immunol Med Microbiol. 43(1):59-65.

Riskesdas (2010). Laporan nasional riset kesehatan dasar tahun 2010 (National report on basic health research in 2010). Badan Penelitian dan Pengembangan Kesehatan Departemen Kesehatan RI.

Rukmini S (2003). Buku ajar ilmu THT untuk perawat (ENT science textbook for nurses). EdisiPertama. Surabaya: FK Airlangga.

Rusmarjono (2003). Buku ajar ilmu kesehatan THT kepala leher Edisi 5 (Textbook of ENT Head Neck Health Sciences Issue 5). Jakarta: FKUI.

Rustam M (2010). Hubungan pemberian ASI eksklusif terhadap kejadian ISPA pada bayi usia 6-12 bulan di Kabupaten Kampar, Provinsi Riau (The relationship of exclusive breastfeeding to the incidence of ARI in infants aged 612 months in Kampar District, Riau Province). Fakultas Kesehatan Masyarakat. PPS Epidemiologi. Depok.

Santoso O, Aditya W, Retnoningrum D (2009). Hubungan kebersihan mulut dan gingivitis ibu hamil terhadap kejadian bayi berat badan lahir rendah kurang bulan di RSUP Dr. Kariadi Semarang danjejaringnya (The relationship of oral hygiene and gingivitis of pregnant women to the incidence of low birth weight infants at less months at the RSUP Dr. Kariadi Semarang and its network). Artikel Penelitian. Media Medika Indonesiana, 43 (6): 288-293.

Sapitri V (2013). Karakteristik penderita tonsillitis kronis yang diindikasikan tonsilektomi di bagian THT Rumah Sakit Umum Raden Mattaher Jambi pada Bulan Mei-Juli 2013 (Charac- 
teristics of patients with chronic tonsillitis indicated tonsillectomy in the ENT section of Raden Mattaher Jambi General Hospital in May-July 2013). Jambi Medical Journal, 1(1): 111.

Satku K (2004). Ministry of health, Singapore nursing management of oral hygiene: Guidelines and recommendations. MOH Nursing Clinical Practice Guidelines 1/2004, Singapore, 14 -24 .

Siswantoro B (2003). Pengaruh tonsilektomi terhadap kejadian bakterimia pascaoperasi (Effect of tonsillectomy on the incidence of postoperative bacteremia). Artikel Penelitian Tesis Bagian Ilmu Kesehatan THT-KL Fakultas Kedokteran Universitas Diponegoro/SMF Kesehatan THT-KL RS Dr. Kariadi, Semarang.

Stapleton FB, Elzouki AY, Harfi HA, Nazer HM, Oh W, Whitley RJ (2012). Textbook of Clinical Pediatrics. Second Edition. Berlin: Heidelberg University.

Story L, Parish T (2008). Breastfeeding helps prevent two major infants' ill- nesses. The Internet Journal of Allied Health Science and Practise; 6(3): 1-5. Sulistyarini (2013). Pengaruh pemberian makanan pendamping ASI (MPASI) tradisional terhadap kejadian ISPA, diare, dan status gizi bayi pada 4 (empat) bulan pertama kehidupannya (Effect of traditional complementary feeding (MPASI) on the incidence of ARI, diarrhea, and infant nutritional status in the first 4 (four) months of life). Jurnal Kesehatan, 6(1): 1-10.

UNICEF Indonesia (2012). Ringkasan kajian kesehatan ibu dan anak (Summary of maternal and child health studies).

Widyastuti A, Nugraha P, Shaluhiyah Z (2018). Perbedaan faktor predisposing, enabling dan reinforcing antara ibu yang memberikan ASI eksklusif dan non ASI Eksklusif di wilayah kerja Puskesmas Boyolali 1 Kabupaten Boyolali Jurnal Kesehatan Masyarakat (E-Journal) 6(1): 704-715.

WHO (2016). Breastfeeding. http://www.who.int/topics/breastfeeding/en/

World Health Organization (2012). World health assembly nutrition target 2025: Breastfeeding policy brief. 